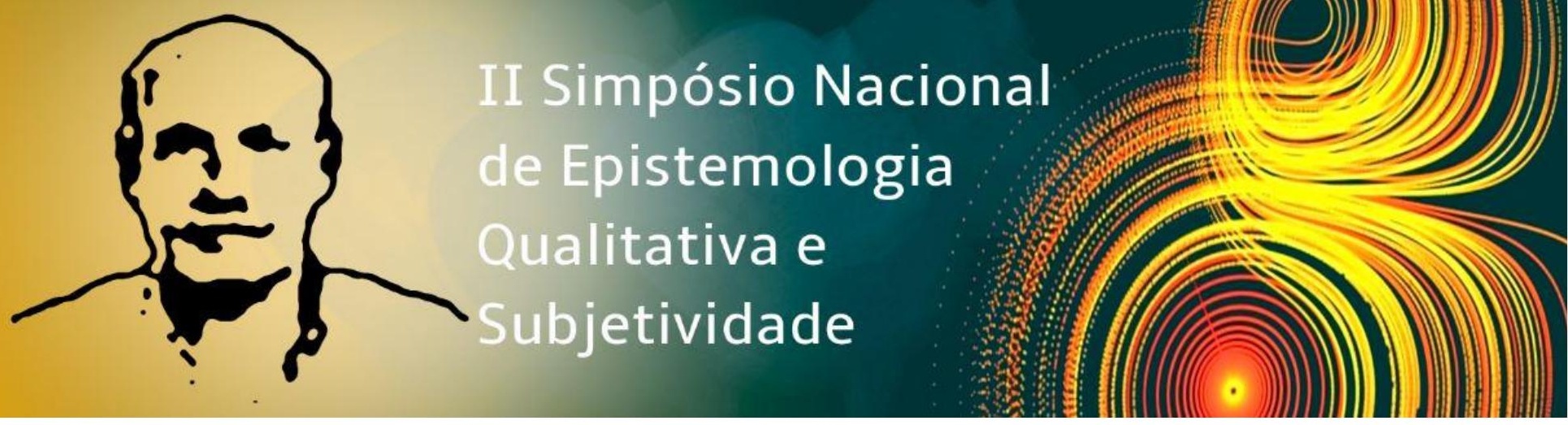

Eixo temático: A subjetividade na formação de professores e outros profissionais

\title{
NEM ROBÔ NEM PROFESSOR: Atuação do intérprete de libras no contexto educacional
}

Luana Luzia da Silva, UFAL, luana.ufal.bio@gmail.com

Neíza Fumes, UFAL, neizaf@yahoo.com

No Brasil, a profissão do tradutor intérprete de Libras foi reconhecida através da Lei 12.319 , de $1^{\circ}$ de Setembro de 2010, Trata-se de uma lei geral que não especifica como deve ser a formação deste profissional para atuar no contexto da sala de aula. Contudo, refletir sobre a formação e a atuação do intérprete educacional faz-se imprescindível, pois, mais do que só ter domínio da Libras e do português, é necessário o entendimento de que no processo educacional:

A questão central não é traduzir conteúdos, mas torná-los compreensíveis, com sentido para o aluno. Deste modo, alguém que trabalhe em sala de aula, com alunos, tendo com eles uma relação estreita, cotidiana, não pode fazer sinais - interpretando - sem se importar se está sendo compreendido, ou se o aluno está aprendendo. Nessa experiência, o interpretar e o aprender estão indissoluvelmente unidos e o intérprete educacional assume, inerentemente ao seu papel, a função de também educar o aluno (Lacerda, 2006 pg. 174).

Este resumo, baseou-se numa pesquisa qualitativa, dentro da perspectiva sociohistórica, e objetivou analisar significações de intérpretes educacionais sobre sua formação e atuação no contexto escolar.

Para a produção dos dados utilizamos a entrevista semiestruturada com quatro intérpretes educacionais de Alagoas, que foi gravada em áudio e posteriormente transcrita.

Ao serem indagados sobre como avaliavam a formação profissional todos os intérpretes a avaliavam como boa, no entanto, três dos quatro intérpretes mencionam dificuldades em disciplina e conteúdos diversos, como geografia e biologia.

Queremos focar neste trabalho as seguintes falas: Eu utilizo mais o classificador, para ajudar o surdo [...] (Intérprete 3) [...] tentar explicar o que é, por meio de outras sinalizações[...]“(intérprete 4)" 


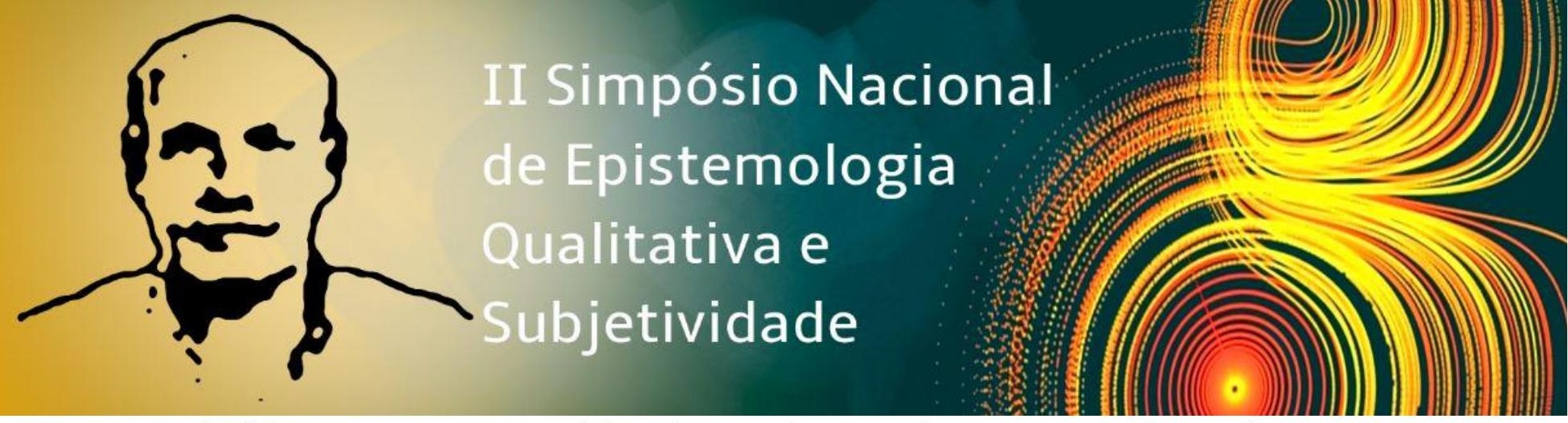

As falas mostram que os sujeitos da pesquisa, conscientemente ou não, praticam sua função pedagógica, que se preocupam com o aprendizado do estudante surdo. Tal entendimento, precisa vir cada vez mais para o campo das significações coletivas do ambiente escolar.

Coadunando com Lacerda (2006), entendemos que, quando se trata do trabalho específico desenvolvido no espaço escolar, os profissionais deste ambiente precisam fazer uma reflexão de que o intérprete educacional é mais que um tradutor dos conteúdos escolares, ele tem função pedagógica ativa, e isto não afasta, ofusca, facilita ou diminui o trabalho dos professores.

Ao contrário disso, professor e intérprete precisam trabalhar juntos para alcançar o principal objetivo de ambos estarem ali, o aprendizado do estudante, logo um trabalho articulado entre estas duas figuras melhorará significativamente este objetivo.

Palavras chave: Intérprete educacional. Atuação profissional. Subjetividade

\section{Referências}

LACERDA, C. B. F. A inclusão escolar de alunos surdos: o que dizem os alunos, professores e intérpretes sobre esta experiência. In: Caderno Cedes, Campinas, v.26, p.163184, 2006.

BRASIL. LEI N ${ }^{\circ} 12.319$, DE $1^{\circ}$ DE SETEMBRO DE 2010. Regulamenta a profissão de Tradutor e Intérprete da Língua Brasileira de Sinais - LIBRAS. 